研究論文

\title{
低炭素社会における廃棄物発電の評柋に関する研究 一維持管理データ分析による電力・エネルギー収支一
}

\section{要旨}

わが国の廃棄物発電はエネルギー政策, 施設整備計画によって推進されてきたが, ダイオキシン類削減施 策により排ガス処理プロセスの高度化, 灰溶融の導入により廃棄物発電システムは大きく変わり, 灰溶融炉 付設システムやガス化溶融システムなど高度な中間処理施設となった。一方，ダイオキシン類対策により施 設の全連続化・広域化は進んだが, 発電規模として望ましいとされる300 t / 日以上の施設は増えず, $300 \mathrm{t}$ ／日未満の施設での発電が多くなっている. 2007年度までに稼動している廃棄物発電の発電量, 購入電力量, 消費電力量, 化石燃料使用量の維持管理データを調査した結果によると, 焼却能力が小さくなるほど消費電 力量が増加し, 溶融に化石燃料を消費しており, 発電はしているもののエネルギー消費型の施設となってい る。今後, さらに大きな広域化によって300 t / 日以上の施設を増やすか, 複数の地域で灰溶融を含めた灰 処理のみ集合化することが必要になると考えられる。

キーワード：廃棄物発電，ごみ焼却，電力・エネルギー収支，維持管理データ

\section{はじめに}

廃棄物発電は国の石油代替新エネルギーとして，ま た廃棄物処理計画でも重点整備として推進されてき た。一方で，焼却処理は様々な環境側面と対峙し，そ の建設された時代に即応した環境対策を第一として技 術開発されてきた経緯もあり，現在では高度な技術と して確立されているといっても良い. 特に環境問題を とりまく種々の課題の解決を図り, サーマルリサイク ルを推進する高いレベルの技術が求められてきた。広 域化を目指した RDF 発電, 高効率化を志向したスー パーごみ発電など普及が進められたが，現実はその評 価も含め大きくは進んでいない. 一方で, 発電推進の なかで小規模施設では IDF 駆動タービンなども実用 化されているが, やはり数多く存在する一般廃棄物発 電を評価する必要がある。
廃棄物発電については高効率計画プロセスや施設の 紹介デー夕などは報告されているが年，実績デー夕 を総合的に分析した報文は見当たらない。ここでは， 現在稼動している施設の維持管理データを分析し, 廃 棄物発電のシステム毎, 燒却能力毎に発電量, 購入電 力量, 消費電力量, 化石燃料投入量から電力収支, 工 ネルギー収支を求め, 今後の方向性を論じる.

この報文では，環境省「日本の廃棄物処理」 ${ }^{4)}$ お よび財)廃棄物研究財団「ごみ焼却施設台帳 [全連続燃 焼方式編］(平成15年度版)」 ${ }^{5)}$ から調査し, 建設中 のものも含めて運転開始時期が1974年 3 月から2007年 12月までの廃棄物発電施設293ヶ所を対象とし, その 運転実績は2003年12月までに運転開始している施設 260 ケ所の 2003 年度の維持管理データをもとにした。
* KEE 環境サービス(株) Shuichi MORIOKA

**岡山大学大学院環境学研究科 Takeshi FUJIWARA

***鳥取環境大学環境マネジメント学科 Masaru TANAKA
2009年 4 月 3 日受付 2009年 5 月26日受理 


\section{1．廃棄物発電に関わる推進経緯と現状}

\section{1 廃棄物発電に関するエネルギー・環境政策 と整備計画}

1991 (平成 3$)$ 年「第 7 次廃棄物処理施設整備計画」 で，ごみ発電への整備投資が重点目標とされこと，通 産省による高効率廃棄物発電技術開発が始められたこ と, 1992 (平成 4 ) 年電力会社による分散型新エネル ギーの余剩電力購入メニューによって廃棄物発電の余 剰電力を原則全量購入する優遇措置が示されことによ り廃棄物発電志向が強くなった。

1994（平成 6 ）年10月の公共投資基本計画で，廃棄 物循環型のごみゼロ社会を目指し，単に燃やして埋め る処理から，極力リサイクルを推進するとともに，焼 却処理の際に発生する熱エネルギーを活用する循環型 の廃棄物処理に転換するとの政策が閣議決定された， 同年12月には石油代替エネルギーの供給目標を達成 し，エネルギー安定供給の確保と地球環境問題から二 酸化炭素の排出削減等を図るための指針として,「新 エネルギー大綱」が定められ、リサイクル型エネルギー として, 廃棄物発電設備の規模を当時現状の約 47 万 $\mathrm{kW}$ から2000年末には200万 $\mathrm{kW} に ， 2010$ 年には400万 $\mathrm{kW}$ に拡大寸る目標が揭げられた。

1998 （平成10）年策定された「長期エネルギー需給 見通し」のなかでも新エネルギーとしての廃棄物発電 は2010年に500万 $\mathrm{kW} の$ 目標とし，2005（平成17）年 には，廃棄物発電+バイオマス発電の目標は450万 $\mathrm{kW}$ となっている。そそして2008（平成20）年「第10次 廃棄物処理施設整備計画」でも，2012（平成24）年に は一般廃棄物での発電を 250 万 $\mathrm{kW}$ とする目標が揭げ られ，推進すべきものとして位置づけられている。

\section{2 廃棄物処理に関わる規制と法整備}

一方では，廃妄物処理施設は種々の環境側面と対峙 しており，特に焼却処理においては環境負荷低減が求 められてきた。その中でも大気規制の変遷に従ってそ の規制を遵守すべく技術開発が行われてきた経緯があ る ${ }^{6}$ ．その規制物質に応じた装置を付加して排ガス処 理プロセスを構成してきたこともあるが，住民合意形 成上種々の上乗せ規制もありその処理プロセスは長大 化してきた. 特にダイオキシン類に関しては, 1997(平 成 9 ) 年大気污染防止法上の指定物質としての排出規 制により，新設 $4 \mathrm{t} / \mathrm{h}$ 以上の全連続炉では排ガス排出 基準值0.1ng-TEQ $/ \mathrm{N} \mathrm{m}^{3}$ と定められ，廃棄物処理法に
おいても規制措置として運転維持管理基準，構造基準 が定められ，より高度な排ガス処理が要求されてきた。

1991（平成 $3 ）$ 年厚生省通達「ごみ処理に係るダイ オキシン類の削減対策について」において，新設の全 連続焼却施設は焼却能力 $300 \mathrm{t} /$ 日程度以上の規模と することが望ましく，最低でも一施設100 t / 日程度 以上とすべきであるとの焼却施設の全連続化・広域化 方針とともに，焼却灰・飛灰の溶融固化施設等を原則 として設置することが通知された。

同年「廃棄物処理法」の大幅改正により焼却飛灰が 特別管理一般廃棄物に指定され，直接埋立処分の禁止， 厚生大臣が定める 4 つの処理法の一つとして溶融固化 が規定された。1996（平成 8 ）年「第 8 次廃棄物処理 施設整備計画」でも，新設の焼却施設はダイオキシン 類の発生防止のため，原則として焼却方式を全連続方 式とし，バグフィルター等の排ガス対策の高度化や焼 却灰のリサイクル，減量化を図るための溶融固化施設 の設置等質的レベルアップを図ることが示された。

これら一連の施策により，焼却処理が大きく様変わ りしてきた。その結果，焼却＋溶融方式に加えガス化 溶融方式が採用されるようになった，廃棄物焼却施設 はこれらの要因によってより高度な中間処理施設と なった結果，維持管理，特に動力負荷の増大を招いて いる状況にある。

\section{2. 廃棄物発電の推移と近年の状況}

\section{1 廃棄物発電計画値と実績値の推移}

廃棄物処理施設は建設期間 $3 \sim 4$ 年を要し運転開始 までに計画段階から 5 年以上必要である。廃棄物発電 施設の稼動は運転開始年度1995年頃から本格化してい る(図 1 )。これは1991年, 廃棄物処理整備計画で発 電等熱利用を重点整備としたこと，ダイオキシン類削 減対策で全連続化・広域化方針が示されたこと，およ び高効率廃棄物発電技術開発が開始されたことによ る。 その後, 2002年に廃棄物発電の施設, 計画発電出 力とも急激に増加している。これは1997年「ダイオキ シン類新ガイドライン」報告から1999年「ダイオキシ ン類対策特別措置法」の成立による一連のダイオキシ ン類対策として施設整備投資が図られたこと，1998年 「長期エネルギー需給見通し」が策定されたことによ る。廃棄物発電は「長期エネルギー需給見通し」の目 標值には届かないものの現行対策維持ケースの值には 到達し，2006（平成18）年現在，稼動実績で総計画発 


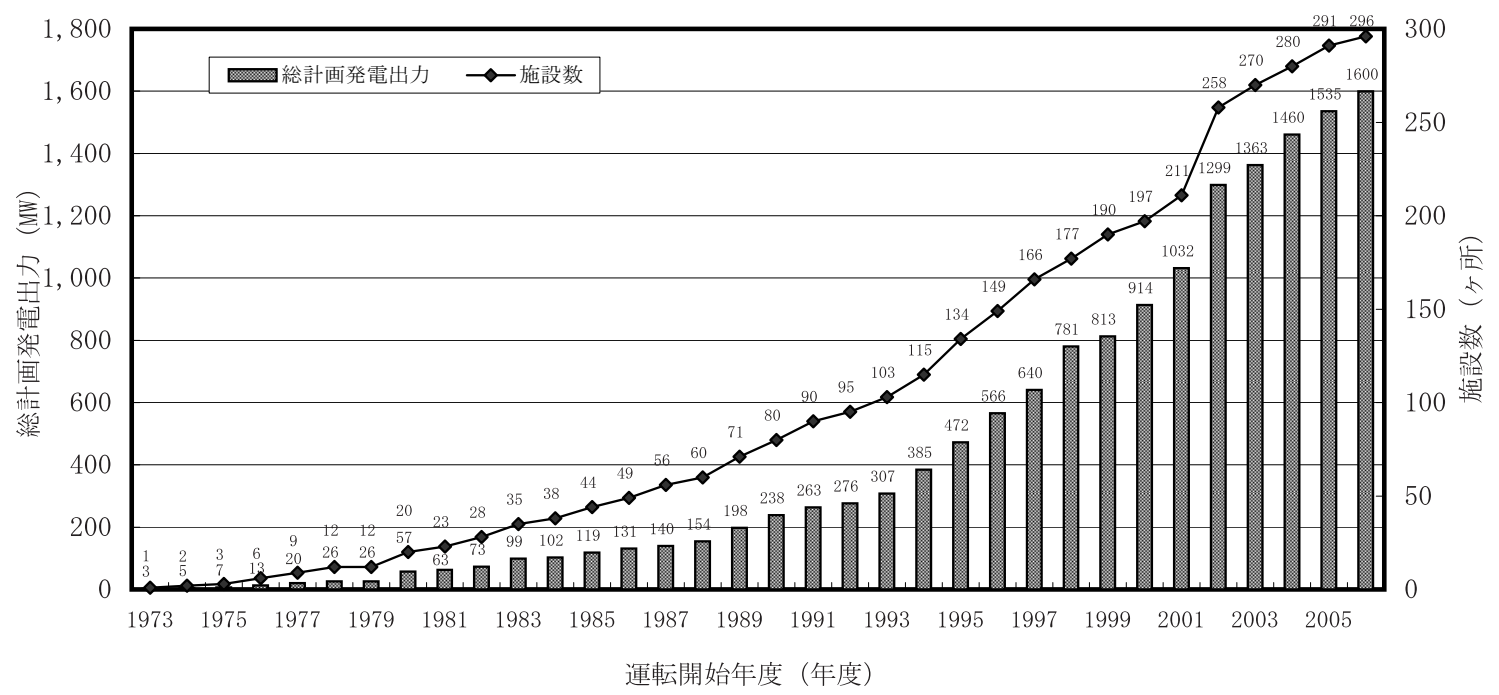

図 1 廃棄物発電の計画発電出力の推移

( $\mathrm{RDF}$ 発電，スーパーごみ発電含む)

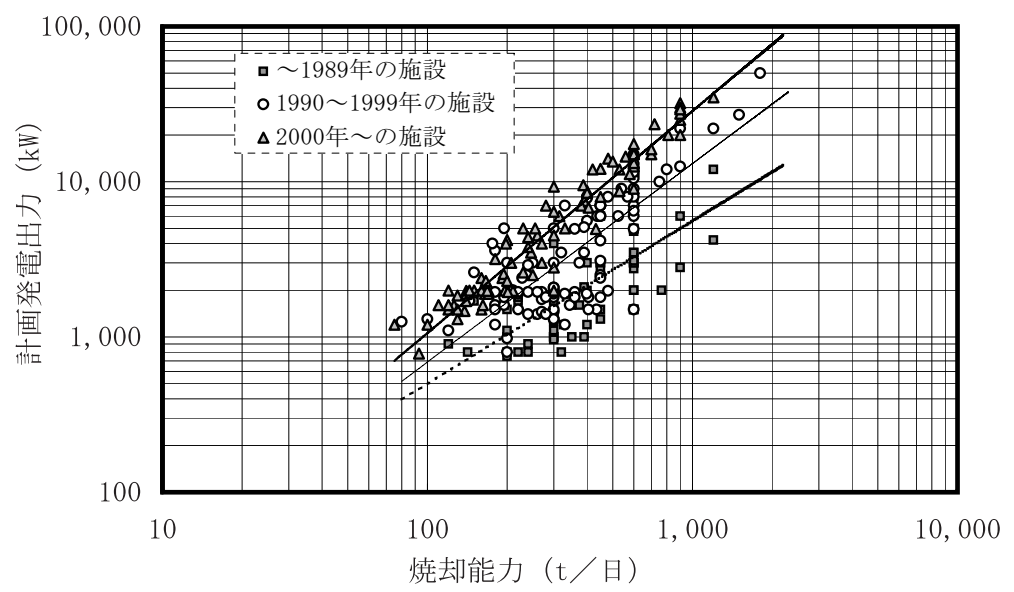

図 2 焼却能力と計画発電出力

(計画発電出力 $500 \mathrm{~kW}$ 以下, スーパーごみ発電, RDF発電, ガスエンジン採用施設を除く)

電能力は約 160 万W となっている.

ボイラ・タービンの計画は1990年代前半温度250〜 $300^{\circ} \mathrm{C}$, 圧力 $2 \sim 3 \mathrm{MPa}, 1995$ 年後半から高温高圧志 向となり, 温度 $400^{\circ} \mathrm{C}$, 圧力 $4 \mathrm{MPa}$, 排気圧力 -70 $-87 \mathrm{kPa}$ の抽気復水タービンが多くなっている.

焼却能力70～ 1800 t ／日の施設で発電されており， 計画発電出力は $1,000 \sim 10,000 \mathrm{~kW}$ 範囲の施設が多く, 最大は50,000kWである(図 2). 約半数の施設は $2,000 \mathrm{~kW}$ 以下であり，これは分散型電源の導入に際し 1986（昭和61）年 8 月「系統連系技術要件ガイドライ ン」（資源エネルギー庁公益事業部長通達）があり，
高圧配電線では原則として $2,000 \mathrm{~kW}$ 未満との規定が あったことにより，特別高圧電線路がない場合 $2,000 \mathrm{~kW}$ 以上では発電施設として制限を受けてきたこ とにもよる.このため, $300 \mathrm{t} /$ 日以上の施設でも $2,000 \mathrm{~kW}$ 未満で設計されている場合がある。焼却能力 と発電計画出力をみると1990年度以前, 1990年代, 2000年代と焼却能力に対して計画発電出力が上がって きており，2006年度現在一施設当たりの計画発電出力 の平均は約 $5,400 \mathrm{~kW}$ である。

実績発電量は年間総発電量 $(\mathrm{kWh} /$ 年) と年間総 燒却量（ $t$ /年）から原単位を求め, ごみの発熱量を 

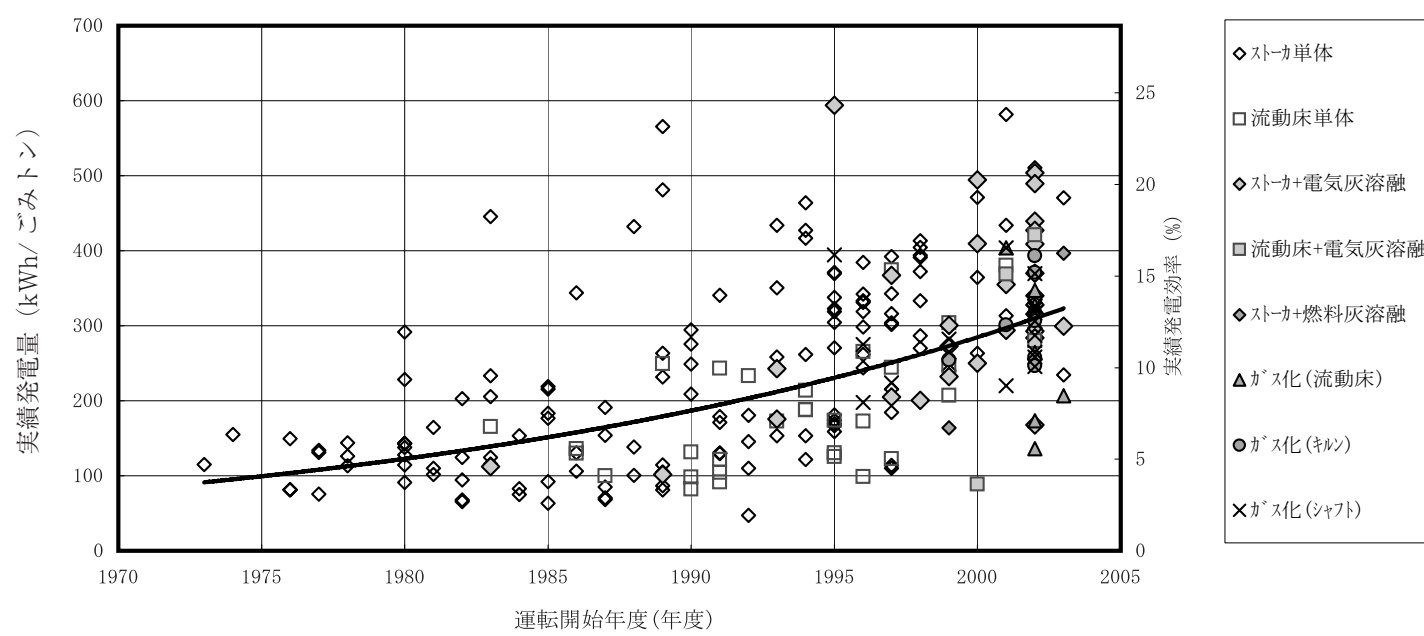

図 3 発電施設の運転開始年度と実績発電量

年度每施設の 2003 年度の運転データ ( $\mathrm{RDE}$ 発電, スーパーごみ発電は除く).

発電効率はごみ発熱量 $2,100 \mathrm{kcal} / \mathrm{kg}(8,790 \mathrm{~kJ} / \mathrm{kg})=2,442 \mathrm{kWh} /$ トンとして計算. 実線は運転開始年度毎の実績発電効率の平均値を結んだ線.

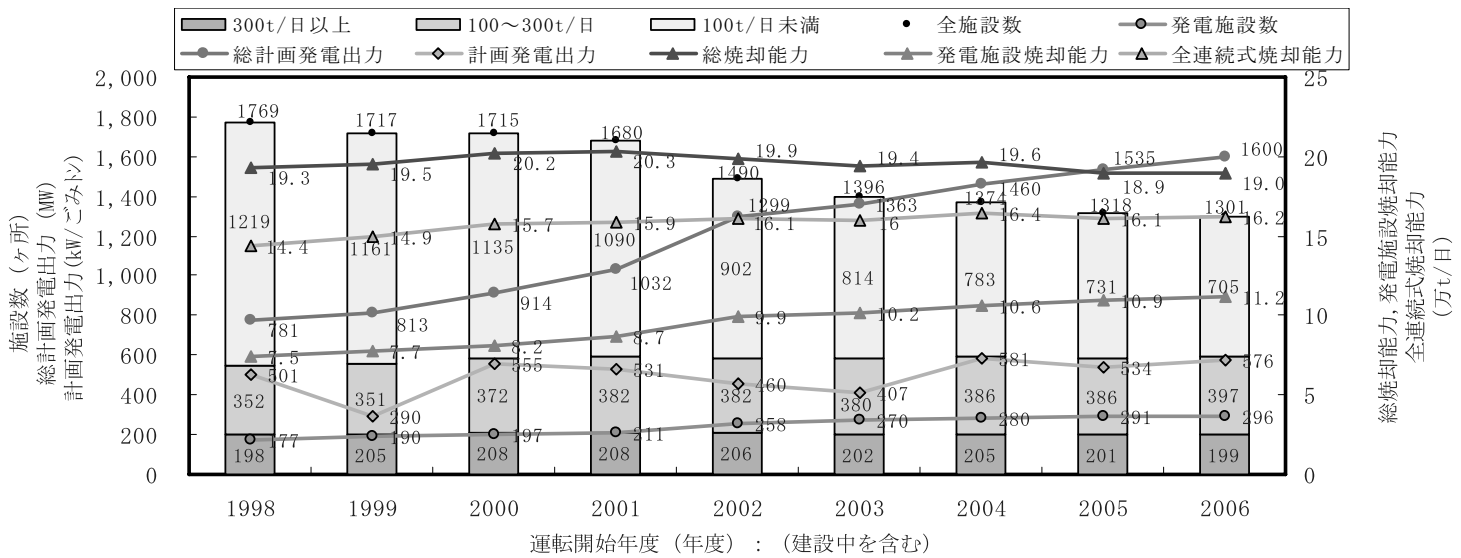

(出展 : 環境省「日本の廃裹物処理」, 廃裹物研究財団「ごみ焼却施設台帳 (平成15年度版)」)

図 4 施設数, 焼却能力, 発電出力の推移

( RDF 発電, スーパーごみ発電含む：計画発電出力は RDF 発電, スーパーごみ発電を含まず)

$2,100 \mathrm{kcal} / \mathrm{kg}(8,790 \mathrm{~kJ} / \mathrm{kg})=2,442 \mathrm{kWh} /$ トンとして 各施設の発電効率を求めた（図 3 )。ごみトン当たり の実績発電量（kWh／ごみトン）は年度施設毎にば らつきはあるが，年々増加傾向である，発電効率 $20 \%$ を超える施設もあるが，2003年度稼動している施設の 実績発電効率の平均は $10 \%$ 強である。

\section{2 近年の状況}

わが国の廃棄物燒却施設は1989（平成元）年当時約 1,900施設，全連続式焼却能力約 12 万 $\mathrm{t} /$ 日であった が，全連続化・広域化方針に従って閉鎖・統合されて
漸減し2006（平成18）年現在では約1,300施設となっ ている（図 4 ）。これは発電に適さない焼却能力の小 さい施設が減少したためであり，ダイオキシン類対策 としては効果があったが, 発電の面から望ましいとさ れる300 $\mathrm{t} /$ /日以上の施設数は大きく変わっていない. 1998 (平成10）年に比べて総焼却能力は約19万 $\mathrm{t} /$ 日 と大きく変わらないが，その一方で総計画発電出力は 約78万 $\mathrm{kW}$ から約 160 万 $\mathrm{kW}$ と倍増している。発電施 設数とその焼却能力は177ヶ所, 7.5 万 $\mathrm{t} /$ 日から 296ヶ所, 11.2 万 $\mathrm{t} /$ 日へと増加している. 
計画発電出力は1998年以前では概ね350kW /ごみ トン以下であったが，1998年以降では平均して約 $500 \mathrm{~kW} /$ ごみトン程度に増えており, 高効率発電を 目指して計画されてきていることがわかる。

焼却能力別では, 焼却能力が大きくなるほど計画発 電出力も大きく, また実績発電量 (実績発電効率) も大 きい(図 5 ). $300 \mathrm{t} /$ 日以上の施設では発電出力約 $450 \mathrm{~kW} /$ ごみトン以上で計画されているが, 実際に施 設が多いのは $100 〜 300 t ／$ 日の施設で，その発電出力

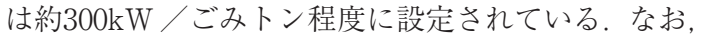
計画発電出力と実績発電量に差があるのは計画ごみ質 と実際のごみ質との相違があるためと考えられる。
この実績発電量を施設毎の焼却能力別，システム別 （図 6 ）でみると，ガス化溶融システムが100～300 t ／日の施設で多く，最終処分場に悩む中小自治体が採 用してきたものであると考えられる。ごみの性状等そ れぞれの施設毎に条件が異なると考えられるが，各シ ステムで実績発電量の差は見られない。これらの施設 では，実績発電効率の平均は15.3\%，焼却施設の稼働 率は約68\%である。

2006年度の全連続式焼却能力は 16.2 万 $\mathrm{t} /$ 日であ り, 発電施設付設の焼却炉の焼却能力が 11.2 万 $\mathrm{t} /$ 日 で計画発電出力約 160 万 $\mathrm{kW}$ である. 目標の 250 万W まで引き上げるためには，稼働率は同じとしてすべて

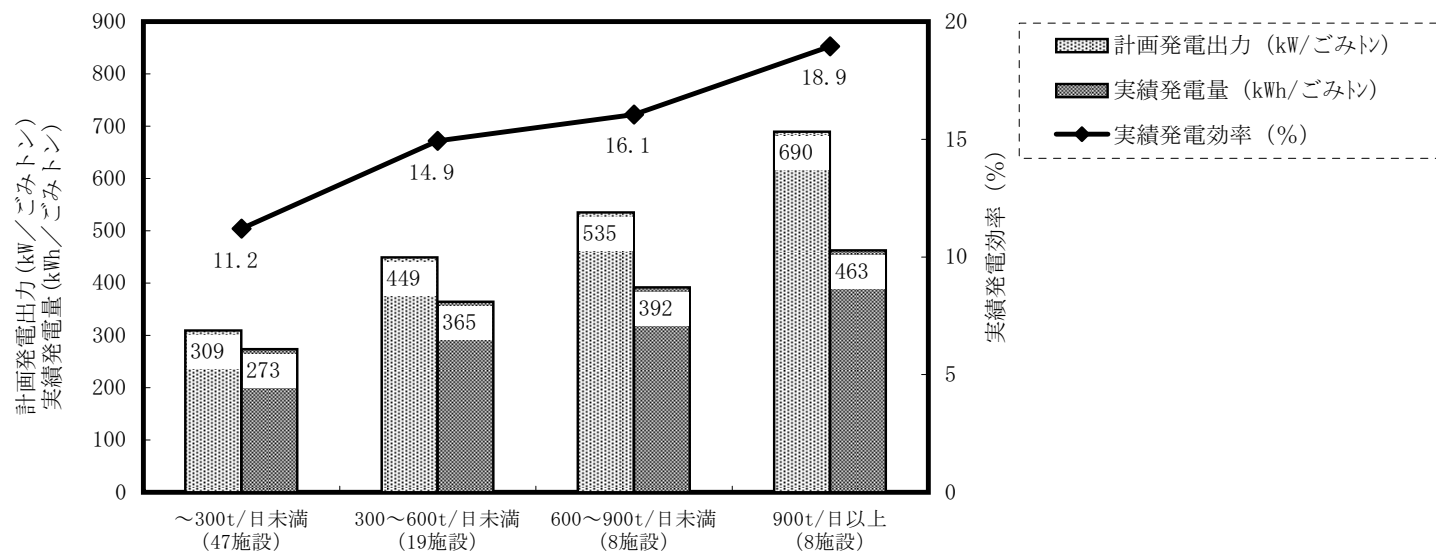

図 5 焼却能力別発電データ (1998年度以降の施設)

維持管理データが揃っている82施設対象（1998～2003年度に運転開始している施設）

* $\mathrm{RDF}$ 発電, スーパーごみ発電除く*発電効率はごみ発熱量 $2,100 \mathrm{kcal} / \mathrm{kg}(8,790 \mathrm{~kJ} / \mathrm{kg})$ として計算

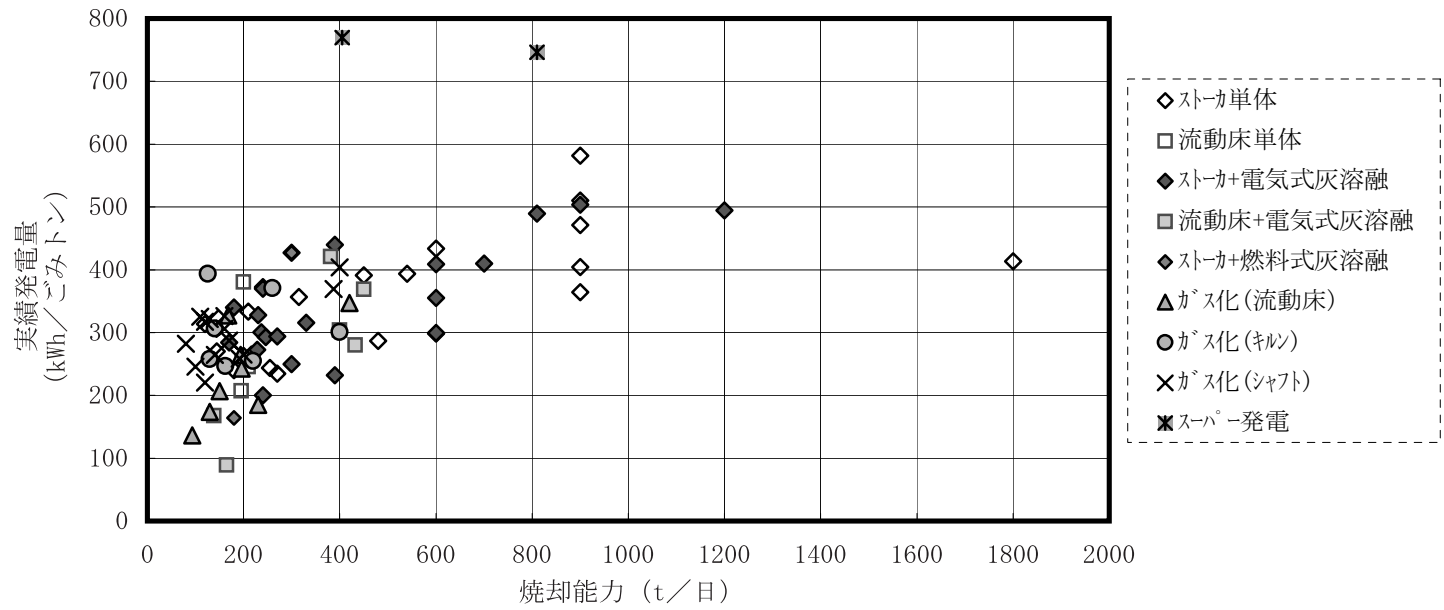

図 6 焼却能力と実績発電量（1998年度以降の施設）

維持管理データが揃っている82施設対象（1998～2003年度に運転開始している施設）＊RDF 発電除く 
の全連続式焼却施設で発電すると仮定すると，今後の 計画発電出力を約 $560 \mathrm{~kW} /$ ごみトンに設定しなけれ ばならず, 燒却能力の大きい施設への移行が望まれる.

\section{3. 発電プロセスデータ}

\section{1 消費電力量, 電力収支}

排ガス処理装置を焼却炬に付加すると通風損失が増 すことから，消費電力は選定する排ガスプロセスに よって大きく変わる。ダイオキシン類対策以前の廃棄 物発電システムではごみトン当りの実績消費電力量は $100 \mathrm{kWh} /$ ごみトン程度であった ${ }^{7)}$. 1990年以前の施 設でもダイオキシン類対策で建設時と異なる排ガス処 理プロセスに更新している場合があり，その場合の実 績消費電力量は100～200kWh /ごみトン程度となっ ている

それ以降の焼却施設ではプロセスとして死溶融炉付 設，キルン炉，流動床炉，シャフト炉などのガス化溶 融システムが導入され，様変わりしてきた結果，実績 消費電力量は高くなってきた。流動床炉はストーカ炉 と比較して砂を流動させることによる機構構造からや や消費電力量は多いが，これらの炉に新たに電気式， 燃料式灰溶融炉が付設されると消費電力量はさらに多 くなる。しかし，ガス化溶融システムは単一プロセス で灰を溶融するシステムであるが，その形式を問わず 消費電力量が多くなっている（図７）。灰溶融炉付設 やガス化溶融という方式の違いにかかわらず，溶融に 招ける投入熱量を安定させるためのごみ破砕・2段
ピットによる攪拌や， スラグ化率向上のための飛灰リ サイクル，スラグ品質向上のための鉄分・アルミニウ 厶分等の選別分離，スラグ破砕等が，消費電力量を押 し上げる要因となっている。

排ガス処理プロセスによって消費電力量が変わるた め，実績消費電力量と焼却能力の相関にはばらつきが あるが，焼却能力が小さくなるほど消費電力量は増え る傾向にある。焼却施設では全炉停止状態から起動す るときにエネルギーが必要であり，電力を購入するこ とがある，その消費電力量は，施設運営計画における 全炉停止回数によって変わる。当然ながら定常運転時 においても消費電力量が多いプロセスでは電力は購入 することになる．

ここでは焼却施設における電力収支を計算する。 データの取り扱い方として, 各実績電力原単位データ の中で, INPUT である発電量と購入電力量をプラス $(+)$, OUTPUT である消費電力量と送電電力量をマ イナス $(-)$ とし, 送電電力量 $=$ 発電量 + 購入電力量 一消費電力量として収支を求めた。購入電力量－送電 電力量で実質の売買電力量を求め, 電とした。システム別の電力収支から（図８），発電 して売電が成立しているのは，ストーカ炉，流動床炉 の単体方式とストーカ + 電気式灰溶融であり, 流動床 + 電気式灰溶融, ストーカ + 燃料式灰溶融, ガス化溶 融システムでは発電しても電力を購入していることに なる，ストーカ+燃料式灰溶融の実績消費電力量につ いては 2 施設のみの実績であり，今後のデー夕蓄積が

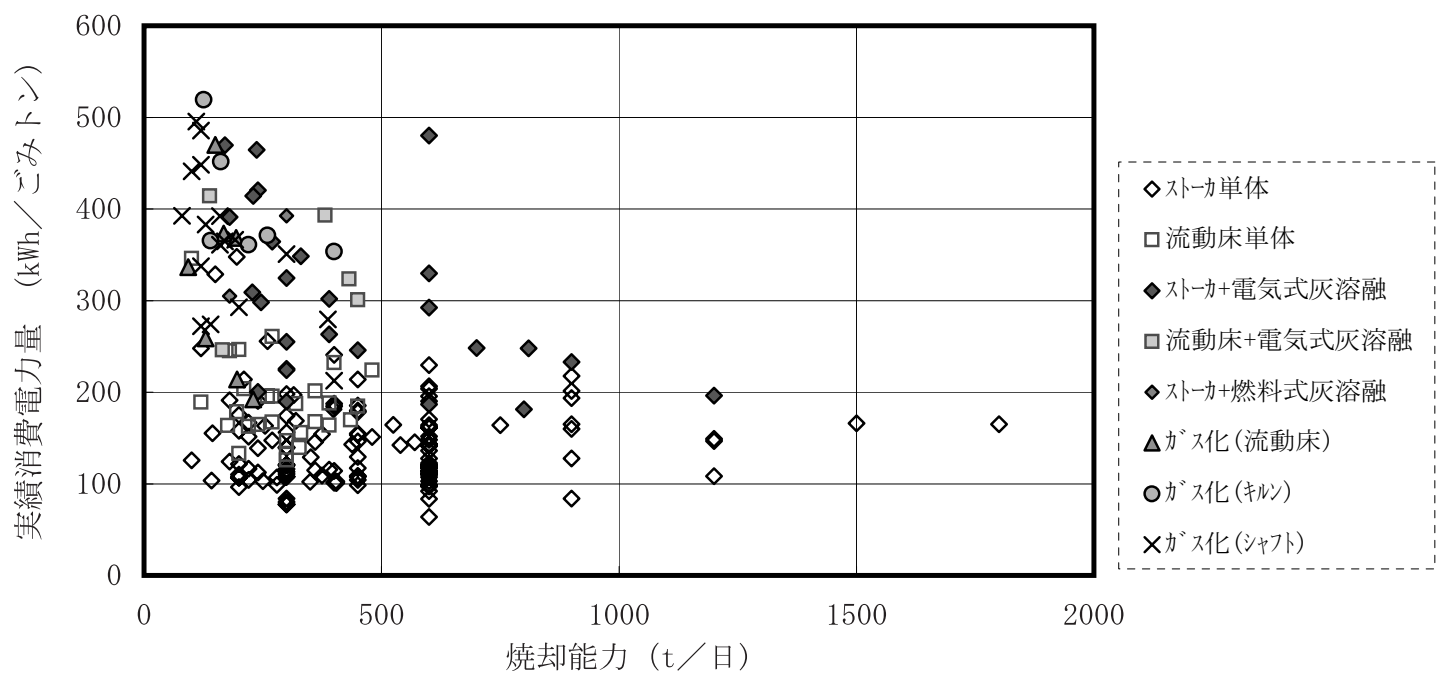

図 7 焼却能力と消費電力量 


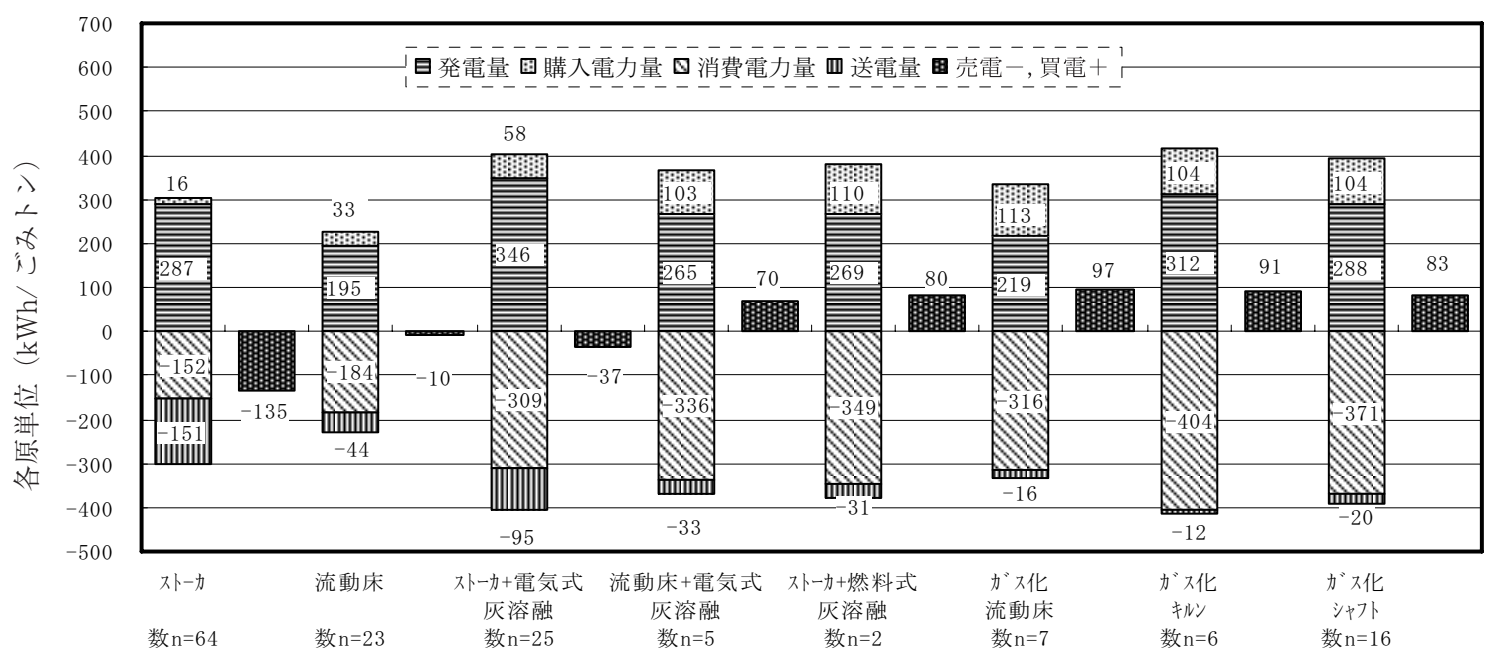

図 8 電力量収支

購入電力量, 消費電力量を+, 発電量, 送電量を-として表示: 数 $\mathrm{n}$ は施設数を表す.

1990 2003年度に運転開始された発電施設192ヶ所のうち 4 項目のデータが揃っている施設148ヶ所の2003年度のデータ

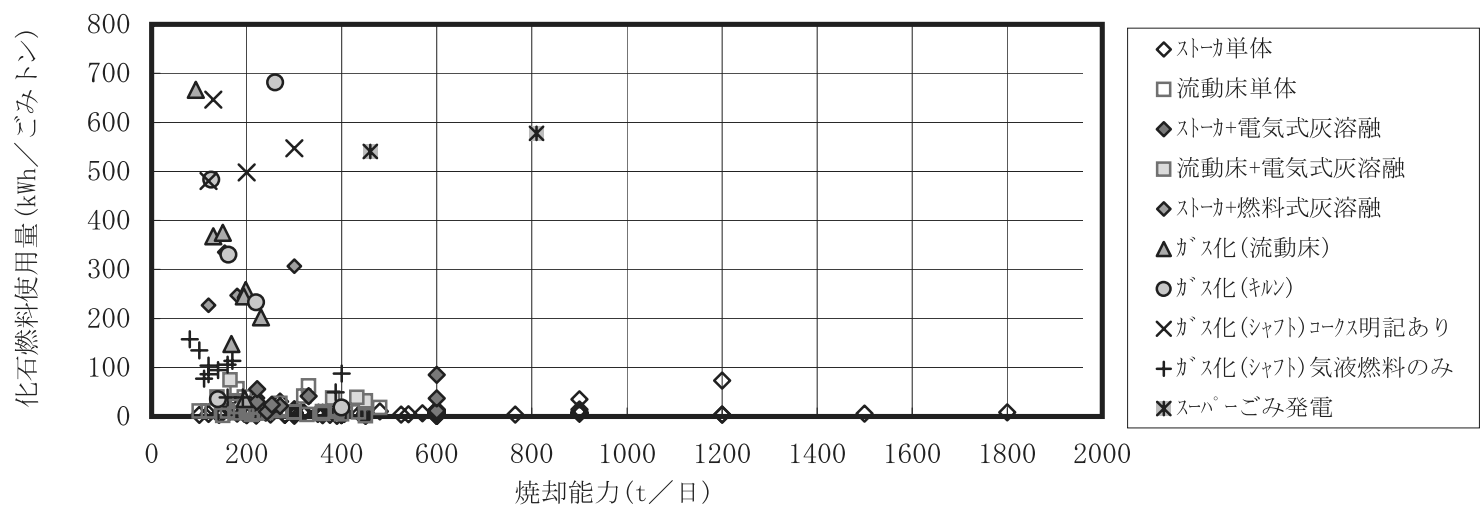

図 9 焼却能力と化石燃料使用量

必要である。ストーカ炉単体の場合, 約 $135 \mathrm{kWh} /$ ご みトンを売電しているが, その他電力購入しているシ ステムでは約70〜90kWh／ごみトンを買電している ことになる ${ }^{8)}$.

\section{2 燃料使用量, エネルギ一収支}

化石燃料使用量は溶融炉の導入が図られた1995年頃 から増えてきており，プラント起動停止時の補助燃料 という一般的な使用に加えて, ダイオキシン類対策で 燃焼温度が規定されたことにより使用する場合もあ る。その量はストーカ, 流動床単体, これらに電気式 灰溶融を付設しても約 $20 \mathrm{kWh} /$ ごみトン以下である. しかし，燃料式灰溶融を付設すると燃料使用量が多く なるのは当然であるが，ガス化溶融システムによって は熱分解加熱や装置構造等から化石燃料を使うものも
あり，ガス化溶融システム全体として化石燃料使用量 は多くなっている，特に焼却能力が小さくなるほど多 くの化石燃料を使用している傾向が強く，その量はご み発熱量の10２5\%程度である（図 9)。スーパーご み発電では500～600kWh／ごみトン使われているが, その分，実績発電量は約 $750 \mathrm{kWh} /$ ごみトンと高く （図 6)，投入した化石燃料のエネルギーの多くは発 電に利用されている。一方, ガス化溶融システムでは, 化石燃料は見かけ上ごみの発熱量を上げて安定な溶融 を図るものであり, 溶融炉体の冷却構造にもよるが,

投入した化石燃料のエネルギーの発電への利用はシス テム全体の発電効率と同じ約10１5\%程度であり，発 電から見た場合のエネルギー投入効果は小さい，そこ で, 各燃料の化石燃料使用量を, 事業用発電効率を 


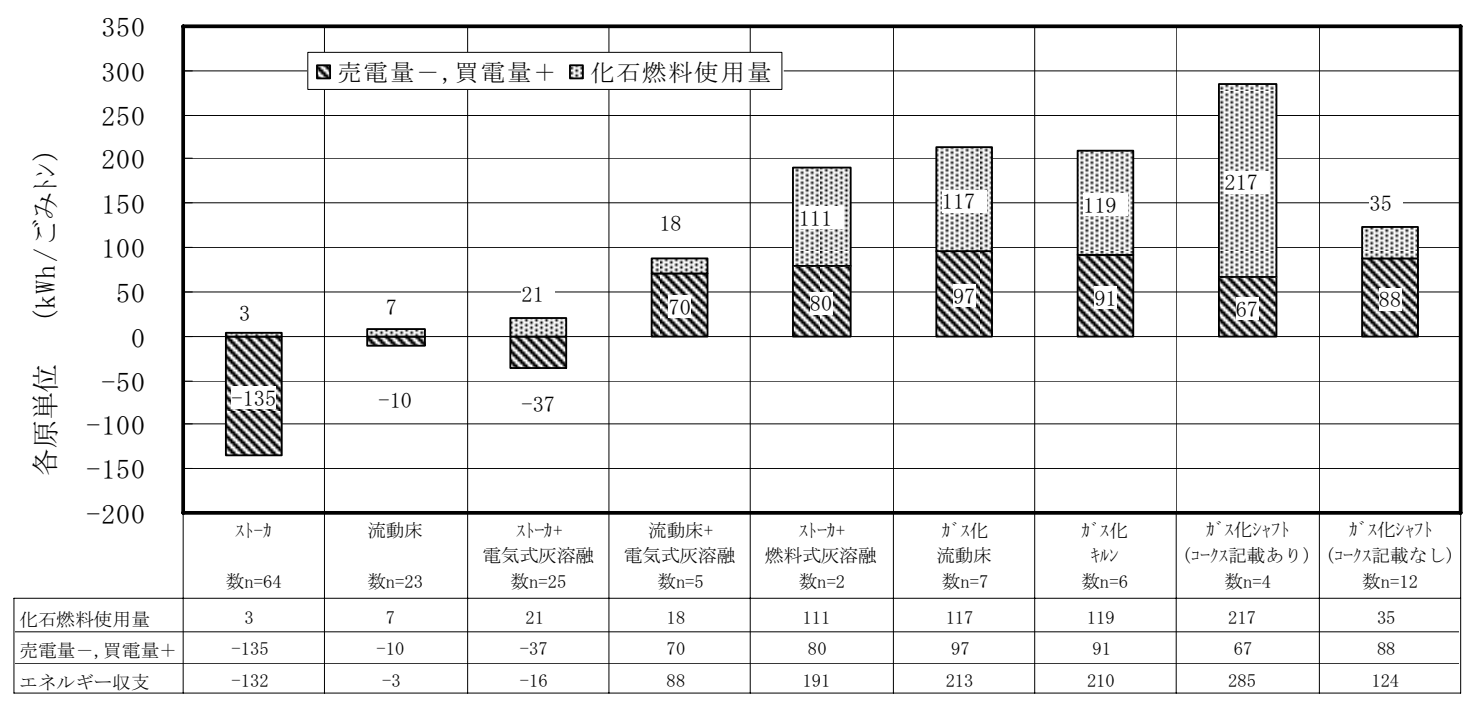

図10 廃棄物発電施設のエネルギー収支

(1)エネルギー収支：+は電力量換算エネルギーを購入, 一は電力量換算エネルギーを売却(2)1990 2003年度に運転開始の発電施設 192ヶ所のうち 4 項目のデータが揃っている施設148ケ所の 2003 年度のデータ (3)化石燃料熱量への電力量換算值：灯油発熱量： $36,418 \mathrm{~kJ} / \ell$, 都市ガス発熱量 : $41,609 \mathrm{~kJ} / \mathrm{m}^{3} \mathrm{~N}$. コークス発熱量 : $25,953 \mathrm{~kJ} / \mathrm{kg}$ の事業用発電効率 $40 \%$ として計算(4)ガス化シャフトは コークス使用明記ない施設が多く, データとしては不備であるが参考として記載.

40\%として電力量換算し, 売電と買電のデータとを合 算して, その電力量換算エネルギー収支を求めた (図10). 計算結果より, 燃料式灰溶融付設とガス化 溶融システムでは, 化石燃料電気量換算值と買電で約 190 280kWh /ごみトンの電力換算エネルギーを購 入していることになる。

\section{3 プロセスデータの考察}

近年の溶融を伴う廃棄物発電施設は, 発電とダイオ キシン類対策, 灰溶融等の各技術を組み合わせた高度 なシステムで実用化されているが，燒却能力が小さい ため, 実績発電量が小さく, 消費電力量, 化石燃料使 用量が多くなり，結果的にエネルギー消費型のシステ ムとなっていて，エネルギー製造型のシステムとは言 えない. 焼却能力が小さい施設では特にエネルギー投 入が必要であり, 発電してはいるが結果的に電力を購 入している. ガス化溶融システムでも焼却能力を大き くすることによって, 消費電力量, 化石燃料投入量を 下げることができると考えられるので, 焼却能力を大 きくすることが必要であろう.

\section{おわりに}

廃棄物発電は廃棄物処理の目的を達成しながら, 国 の新エネルギー政策から石油代替エネルギーとして位 置づけられ，推進されてきた。また，地球環境保全の
視点からも廃棄物の適正処理, エネルギー回収の位置 づけは変わっていない ${ }^{9)}$ ，そして，それに応える技術 で施設は建設されてきたが，廃棄物焼却処理に対する 風当たりは強く, 種々の規制の中でシステムが考案さ れた結果，プロセスが複雑となりつつある。

この調査研究の結果, 焼却能力 $300 \mathrm{t} /$ 日以下の廃 棄物発電では, 灰溶融付設システム, ガス化溶融シス テムを含めて, 発電はするものの所内動力に電力を費 やし，その維持管理用にもエネルギー消費の増加を招 いてエネルギー多消費型のものになりつつある現状が 明らかとなった。

今後の廃棄物発電は焼却能力 $300 \mathrm{t} /$ 日以上の場合 にはガス化溶融を含めて灰溶融を自己完結する方式が 良い。また，長期プランを考えた場合，250万 $\mathrm{kW} の$ 廃棄物発電を目指すためには, 発電効率をさらに高め て, 計画発電出力を $500 ６ 00 \mathrm{~kW}$ ／ごみトンとする必 要があり, さらなる焼却能力の大きなものに集約する か, 広域的な灰溶融を含めた灰処理集合設備を設ける などエネルギー消費を削減する施策も必要になると考 えられる。この場合，インフラとして大きな施設には 特別高圧線の整備が必要であり, 高圧線利用の小さな 施設では系統連系技術ガイドラインでの協議で発電出 カのアップも必要となる。 さらに, 所内エネルギー消 費を減少させるために, 白煙防止を含めて過大な環境 
基準は避け，排ガス処理プロセスを簡素化することも 考える必要がある，大きな広域化を含めて，環境とコ ストの考え方は十分な理解と合意形成が必要である.

\section{文献}

1 ) 小川紀一郎；新エネルギーの技術動向 8 廃棄物発電, 電気設備学会誌，27，(8)，645-648, 2007.

2 ) 守岡修一; 廃棄物発電の現状と今後, 日本機械学会関西 支部226回講習会「新エネルギー，未知エネルギー活用の 現状と将来」, 1997.

3 ）芝川重博, 内山典人, 山田良一; 大型廃棄物発電設備の 事例紹介と高効率化の検討, 第74回日本機械学会関西支 部定時総会講演会講演論文集, 1.11-1.12, 1999.

4 ）環境省大臣官房廃棄物リサイクル対策部；一般廃棄物処
理事業実態調査結果 日本の廃棄物処理 (平成18年度版), 2008 .

5 ) (財)廃棄物研究財団 ; ごみ焼却施設台帳「全連続焼却施設 編」(平成15年度版)， 2005 .

6 ）守岡修一；ごみ焼却を考える 大気規制の変遷と技術開 発，環境技術，7，(3)，184-190, 1998.

7 ）清掃工場の運営と管理編集委員会; 清掃工場の運営と管 理, 工業出版社, 104, 1986.

8 ) 川本克也；循環型社会の視点からみたガス化溶融方式焼 却施設の実態と評価, 都市清掃, 61, (285), 2008.

9 ) (財新エネルギー財団 新エネルギー産業会議; 廃棄物発電 システムの導入促進に関する提言, 2004.

\title{
Evaluation of Waste to Energy Facilities in Japan \\ - Electricity and Energy Balance based on Analysis of Operation and Maintenance Data -
}

\author{
Shuichi MORIOKA *, Takeshi FUJIWARA **, Masaru TANAKA *** \\ * Kawasaki Environmental Plant Operation Servise,Ltd. \\ * * Graduate School of Environmental Science,Okayama University \\ *** Department of Environmental Management,Tottori University of Environmental Studies
}

ABSTRACT

The policy of waste to energy (WTE) has been promoted as an important policy for alternative energy and one of the principle infrastructure plans of the Japanese government. However, problems with dioxin have necessitated various changes of WTE technology, and WTE facilities now must have flue gas treatment equipment with long-chain process, ash melting furnace, and gasification and melting furnace. Although WTE facilities with the disposal capacity of $300 \mathrm{t} / \mathrm{d}$ or greater have been considered to be more effective and desirable, the number of these facilities has not increased, and WTE facilities with capacity of less than 300t/d have been increasing in compliance with the dioxin guidelines for continuous combustion and regional waste disposal.

This study investigates and analyzes the generation, purchase and consumption of electricity / fossil fuels using the operation and maintenance data of all of WTE facilities operated in 2007 in Japan. Our findings show that the smaller the capacity of WTE facility, the greater the consumption of electricity and energy per ton. In the future it may be recommended that WTE facilities of 300t/d or greater be increased and the ash from several WTE facilities be treated jointly.

Key Words: Waste to Energy, Municipal Solid Waste Combustion, Energy Balance in terms of Power and Fuel, Operation and Maintenance Data 